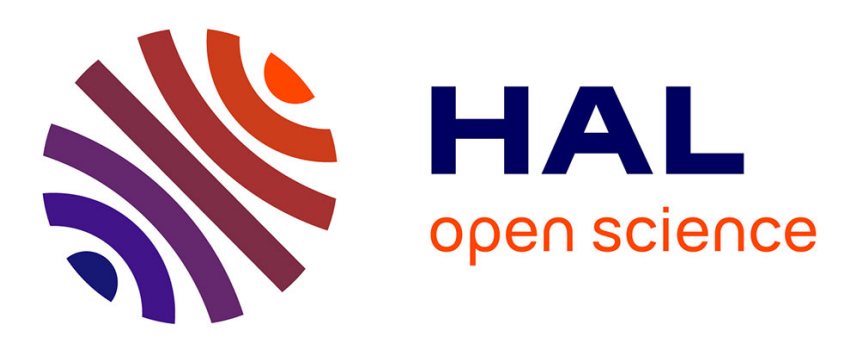

\title{
Optimization of enzymatic hydrolysis and fermentation conditions for improved bioethanol production from potato peel residues
}

\author{
Imen Ben Taher, Patrick Fickers, Sofien Chniti, Mnasser Hassouna
}

\section{- To cite this version:}

Imen Ben Taher, Patrick Fickers, Sofien Chniti, Mnasser Hassouna. Optimization of enzymatic hydrolysis and fermentation conditions for improved bioethanol production from potato peel residues. Biotechnology Progress, 2017, 33 (2), pp.397-406. 10.1002/btpr.2427 . hal-01518035

HAL Id: hal-01518035

https://hal-univ-rennes1.archives-ouvertes.fr/hal-01518035

Submitted on 19 May 2017

HAL is a multi-disciplinary open access archive for the deposit and dissemination of scientific research documents, whether they are published or not. The documents may come from teaching and research institutions in France or abroad, or from public or private research centers.
L'archive ouverte pluridisciplinaire HAL, est destinée au dépôt et à la diffusion de documents scientifiques de niveau recherche, publiés ou non, émanant des établissements d'enseignement et de recherche français ou étrangers, des laboratoires publics ou privés. 


\section{Optimization of enzymatic hydrolysis and fermentation conditions for improved bioethanol production from potato peel residues}

\section{Imen BEN TAHER ${ }^{* 1,2}$, Patrick FICKERS ${ }^{3}$, Sofien $\mathrm{CHNITI}^{4}$, Mnasser HASSOUNA ${ }^{1}$}

1. Unité de recherche Sciences des Aliments, Ecole Supérieure des Industries Alimentaires de Tunis, Av Alain Savary, 58, 1003, Tunis, Tunisia

2. Laboratoire de génies biologique et agroalimentaire, Université Libre de Tunis, Av Kheireddine Pacha, 30, 1002 Tunis, Tunisia

3. Microbial Processes and Interaction, Gembloux AgroBioTech-Université de Liège, Passage des déportés, 2, 5030, Gembloux, Belgium.

4. 4. Université de Rennes 1, ENSCR, CNRS, UMR 6226, avenue du Général Leclerc, CS 50837, 35708 Rennes Cedex 7, France

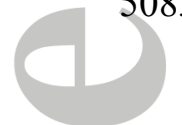

Corresponding author: Imen BEN TAHER, imen_bentahar@yahoo.fr, Tel: (+216) 71902 811, Fax: (+216) 71906960

\section{List of mail address}

Patrick FICKERS (pfickers@ulg.ac.be)

Sofien CHNITI (sofien.chniti@hotmail.fr)

Mnasser HASSOUNA (mnasser.hassouna@isbb.rnu.tn)

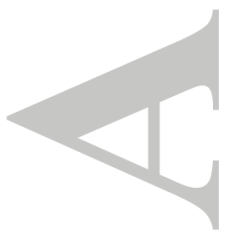




\section{Abstract}

The aim of this work was the optimization of the enzyme hydrolysis of potato peel residues (PPR) for bioethanol production. The process included a pretreatment step followed by an enzyme hydrolysis using crude enzyme system composed of cellulase, amylase and hemicellulase, produced by a mixed culture of Aspergillus niger and Trichoderma reesei. Hydrothermal, alkali and acid pretreatments were considered with regards to the enhancement of enzyme hydrolysis of potato peel residues. The obtained results showed that hydrothermal pretreatment lead to a higher enzyme hydrolysis yield compared to both acid and alkali pretreatments. Enzyme hydrolysis was also optimized for parameters such as temperature, $\mathrm{pH}$, substrate loading and surfactant loading using a response surface methodology. Under optimized conditions, $77 \mathrm{~g} / \mathrm{L}$ of reducing sugars were obtained. Yeast fermentation of the released reducing sugars led to an ethanol titer of $30 \mathrm{~g} / \mathrm{L}$ after supplementation of the culture medium with ammonium sulfate. Moreover, a comparative study between acid and enzyme hydrolysis of potato peel residues was investigated. Results showed that enzyme hydrolysis offers higher yield of bioethanol production than acid hydrolysis. These results highlight the potential of second generation bioethanol production from potato peel residues treated with onsite produced hydrolytic enzymes.

Keywords: potato peel residues, pretreatment, enzymatic hydrolysis, bioethanol, response surface methodology

\section{Introduction}

Nowadays, the potential use of lignocellulosic biomass for bioethanol production attracts much attention ${ }^{1}$. In 2014, worldwide bioethanol production hit a record 92 billion liters ${ }^{2-}$ 4. The most commonly used lignocellulosic substrates for bioethanol production are sugarcane and corn ${ }^{5,6}$. However, these materials are high value-added products and are considered as food sources. In fact, bio-refinery industries are seeking alternative nonedible and cheaper biological materials such as abundantly available agricultural feedstock or by-products to fulfill the global bioethanol demand ${ }^{7}$. In this study, we studied potato peel residue (PPR) as an advantageous bio-energy source that could be exploited for bioethanol production as it contains high amounts of starch and cellulose ${ }^{8}$. 
Worldwide potato production was estimated to 350 million tons in $2012^{9}$. During industrial processing of potatoes, approximately $40 \%$ of the potatoes are wasted, principally as peel $^{7}$. Statistics estimate that nearly two million tons of potato peel are generated per year from potato processing ${ }^{9}$. PPR were incorporated in some animal feed formulation ${ }^{10}$. Whereas, it was indicated that animal feed prepared from this kind of waste have low nutritional values ${ }^{11}$. Moreover, many previous studies identify different antioxidant and antimicrobial molecules that can be extracted from PPR ${ }^{12,13}$. However, the economic feasability of the extraction processes of these molecules limit their application $^{14}$. Given their low cost, availability and adequate biochemical composition, PPR can be used as feedstock for bioethanol production. However, the process still requires optimization. Indeed, cellulose, starch, and hemicellulose, the main components of the matrix, cannot be metabolized directly by microorganisms and converted to bioethanol. The material must first be hydrolyzed to fermentable sugars by enzyme or acid catalysis. Enzyme hydrolysis is claimed to be an appropriate method for the conversion of lignocellulosic biomass into bioethanol since it affords numerous advantages such as mild reaction conditions and high yield without producing toxic byproducts $^{15}$. Agricultural feedstocks and byproducts are composed of polysaccharide polymers that are stubborn to microbial degradation. In addition, these polysaccharides are associated with lignin, which acts as a physical barrier that protects polysaccharides from enzyme action ${ }^{16}$. Therefore, prior to enzyme hydrolysis, a pretreatment step is mandatory to modify the structure of the lignocellulosic matrix and make it more accessible to the enzymes. Pretreatments aim to depolymerize lignin, increase the porosity of the matrix, solubilize hemicellulose and starch, decrease cellulose crystallinity, and consequently increase its digestibility ${ }^{17,}{ }^{18}$. Various pretreatment methods, such as ammonia fiber explosion, acid pretreatment, and steam explosion, have been reported ${ }^{19}$. However, the choice of the pretreatment method is of high importance and must take into account the following requirements: (1) it must improve the enzymatic conversion of carbohydrates into fermentable sugars;(2) there should be little or no degradation or loss of carbohydrates during the pretreatment;(3) there should be no generation of toxic compounds that could inhibit subsequent enzyme hydrolysis and fermentation processes; and (4) it should be inexpensive. Enzyme hydrolysis of the pretreated biomass aims to convert carbohydrate polymers into fermentable monomer sugars. The efficiency of enzyme hydrolysis is governed by several process parameters 
such as substrate loading, reaction time, $\mathrm{pH}$, or temperature ${ }^{20}$. Since the effects of these parameters are correlated, optimization of enzyme hydrolysis conditions is a key factor to improving process efficiency. Optimization of factors independently is considered as a laborious and time-consuming approach. An alternative method based on the use of response surface methodology (RSM) is considered a better approach for optimization studies. RSM is a statistical method that analyzes the effect of multiple factors individually or in combination in a minimal number of experiments. It is an efficient approach that could be applied to optimize the enzyme hydrolysis of lignocellulosic substrates $^{21,22}$.

A survey of recent literature showed that data on the production of bioethanol from PPR is rather scarce. Therefore, the aim of the present study was to develop a useful strategy using RSM to optimize pretreatment of PPR and enzyme hydrolysis process by a crude enzyme system produced by a mixed culture of Aspergillus niger and Trichoderma reesei in order to valorize PPR as a substrate for bioethanol production.

\section{Materials and Methods}

\subsection{Collection of PPR}

PPR was collected from local restaurants in Tunis (Tunisia). They were washed with water to remove undesirable particles and dried in a forced-air oven at $45^{\circ} \mathrm{C}$ until a constant weight was obtained followed by milling in a home processor. It was stored at room temperature until further use.

\subsection{Microorganisms}

T. reesei strain DSMZ 970 and A. niger strain ATCC 16404 were grown on potato dextrose agar (Biokar, France). After incubation at $30^{\circ} \mathrm{C}$ for 5 days, spores obtained were resuspended in sterile distilled water containing $0.1 \%(\mathrm{v} / \mathrm{v})$ tween 80 . A commercial bakery strain of Saccharomyces cerevisiae(La Pâtissiére, Tunisia) was used for the fermentation step and bioethanol production. The strain was preserved on yeast extract agar at $4{ }^{\circ} \mathrm{C}$ until further use.

\subsection{Production of crude enzyme}


In $250 \mathrm{~mL}$ Erlenmeyer flasks, $30 \mathrm{~g}$ PPR was moistened with distilled water to obtain a final moisture content of $70 \%$. The mixture was sterilized at $120^{\circ} \mathrm{C}$ for $15 \mathrm{~min}$, cooled, and then inoculated with $10^{3}$ spores $/ \mathrm{mL}$ of both $T$. reesei and A. niger strains. Cultures were maintained at $30^{\circ} \mathrm{C}$ for 4 days in a bacteriological incubator. Further, $10 \mathrm{~mL}$ of distilled water was added to the fermented mash before being stirred in a rotary shaker at $100 \mathrm{rpm}$ for $1 \mathrm{~h}$ and centrifuged at $3000 \mathrm{~g}$ for $10 \mathrm{~min}$ at $4^{\circ} \mathrm{C}$. The resulting supernatant, containing cellulase, hemicellulase, and amylase, was used as a crude enzyme extract to convert complex carbohydrates (i.e., cellulose, hemicellulose, and starch) into fermentable sugars.

\subsection{Pretreatment of PPR}

PPR was subjected to three different pretreatments as follows: acid, alkali, and hydrothermal pretreatment and an untreated sample was used as a control. The choice of these pretreatment conditions is based on previous studies ${ }^{23-25}$. The residue was dispersed separately in distilled water, $1 \%(\mathrm{v} / \mathrm{v})$ sulfuric acid $\left(\mathrm{H}_{2} \mathrm{SO}_{4}\right)$ solution, or $1 \%(\mathrm{w} / \mathrm{v})$ sodium hydroxide $(\mathrm{NaOH})$ solution at a solid to liquid ratio of $1: 10$ before being heated at $121^{\circ} \mathrm{C}$ for $30 \mathrm{~min}$. Further, the $\mathrm{pH}$ of acid and alkali pretreated samples was adjusted to 7, filtered, and rinsed with distilled water to remove chemical residues. Finally, all the samples were dried in an oven at $40^{\circ} \mathrm{C}$ until a constant weight was obtained.

\subsection{Enzyme hydrolysis of PPR}

\subsubsection{Effect of pretreatment on enzyme hydrolysis}

Hydrolysis experiments were conducted in $150 \mathrm{~mL}$ stopper conical flasks containing $10 \mathrm{~g}$ of pretreated substrate, crude enzyme extract, $100 \mathrm{~mL} 0.1 \mathrm{M}$ acetate-phosphate buffer ( $\mathrm{pH}$ 5.5), and $200 \mu \mathrm{L}$ antibiotic solution (streptomycin - penicillin 10 units $/ \mathrm{mL}$ ) to prevent microbial contamination. The loading of cellulase, hemicellulase, and amylase were $30 \mathrm{U} / \mathrm{gds}$ (g of dry substrate), $5 \mathrm{U} / \mathrm{gds}$, and $70 \mathrm{U} / \mathrm{gds}$, respectively. The flasks were incubated at $50^{\circ} \mathrm{C}$ in a rotary incubator at $100 \mathrm{rpm}$ for $48 \mathrm{~h}$. Further, samples were centrifuged at $6000 \mathrm{~g}$ for $10 \mathrm{~min}$ and the supernatant was collected and analyzed for the content of reducing sugars.

\subsubsection{Statistical optimization of hydrolysis conditions by Box-Behnken design}


A three level four-factorial Box-Behnken design (BBD), was employed in order to evaluate the influence of temperature, $\mathrm{pH}$, substrate concentration, and surfactant concentration on the hydrolysis yield of the substrate. Hydrothermally pretreated PPR was used as a model substrate. An analysis at different levels (high, medium, and low) represented by coded symbols $+1,0,-1$, respectively, was performed for each variable. The variable input parameters were temperature $\left(30-60^{\circ} \mathrm{C}\right), \mathrm{pH}(5-8)$, substrate concentration $(2-10 \% \mathrm{w} / \mathrm{v})$, and surfactant concentration $(0-1 \% \mathrm{v} / \mathrm{v})$; the concentration of reducing sugars was the output parameter. All statistical analyses were conducted using Minitab version 17 (Minitab, USA). The mathematical relationship between the output (reducing sugars concentration) and the independent variables (temperature, $\mathrm{pH}$, substrate concentration, and surfactant concentration) could be presented by this equation (Eq1).

$$
\begin{gathered}
\mathrm{Y}=\mathrm{a}_{0}+\mathrm{a}_{1} \mathrm{~V}_{1}+\mathrm{a}_{2} \mathrm{~V}_{2}+\mathrm{a}_{3} \mathrm{~V}_{3}+\mathrm{a}_{4} \mathrm{~V}_{4}+\mathrm{a}_{11} \mathrm{~V}_{1}^{2}+\mathrm{a}_{22} \mathrm{~V}_{2}^{2}+\mathrm{a}_{33} \mathrm{~V}_{3}^{2}+\mathrm{a}_{44} \mathrm{~V}_{4}{ }^{2}+\mathrm{a}_{12} \mathrm{~V}_{1} \mathrm{~V}_{2}+\mathrm{a}_{13} \mathrm{~V}_{1} \mathrm{~V}_{3} \\
+\mathrm{a}_{14} \mathrm{~V}_{1} \mathrm{~V}_{4}+\mathrm{a}_{23} \mathrm{~V}_{2} \mathrm{~V}_{3}+\mathrm{a}_{24} \mathrm{~V}_{2} \mathrm{~V} 4+\mathrm{a}_{34} \mathrm{~V}_{3} \mathrm{~V}_{4}
\end{gathered}
$$

where $\mathrm{Y}$ is the predicted value of the concentration of reducing sugars, $\mathrm{a}_{0}$ is the constant, $\mathrm{V}_{1}$ is the temperature, $\mathrm{V}_{2}$ is the $\mathrm{pH}, \mathrm{V}_{3}$ is the substrate concentration, and $\mathrm{V}_{4}$ is the surfactant concentration. $a_{0}$ is the offset term, whereas $a_{1}, a_{2}, a_{3}$, and $a_{4}$ are linear coefficients. $a_{12}, a_{13}$, $\mathrm{a}_{14}, \mathrm{a}_{23}, \mathrm{a}_{24}$, and $\mathrm{a}_{34}$ are cross-product coefficients, and $\mathrm{a}_{11}, \mathrm{a}_{22}, \mathrm{a}_{33}$, and $\mathrm{a}_{44}$ are quadratic coefficients.

\subsection{Acid hydrolysis of PPR}

Hydrochloric acid ( $\mathrm{HCl}$ ) was used to achieve acid hydrolysis of PPR according to a previously described method ${ }^{26}$. Hydrothermally pretreated PPR (10 g) was dispersed in 5\% $(\mathrm{v} / \mathrm{v}) \mathrm{HCl}$ solution at a solid to liquid ratio of $1: 10(\mathrm{w} / \mathrm{v})$ before being heated at $100^{\circ} \mathrm{C}$ for 120 min. Further, the $\mathrm{pH}$ of the mixture was adjusted to 5 with $\mathrm{NaOH}$ solution $(2 \mathrm{M})$ and filtered to remove solid particles.

\subsection{Bioethanol production}

In the first step, acid and enzyme hydrolysates were compared for bioethanol production.PPR hydrolysates obtained from both enzyme and acid hydrolysis were used as substrate. In the second step, the effect of nitrogen addition on bioethanol production from enzyme hydrolysate was tested. Three different alcoholic fermentation experiments were 
conducted as below: without nitrogen addition, with ammonium sulfate addition $(0.15 \mathrm{~g} / \mathrm{L})$, and with peptone addition $(1 \mathrm{~g} / \mathrm{L})$. The choice of the inorganic nitrogen concentration is based on a previous study ${ }^{27}$ and the choice of peptone concentration is based on the research reported by Fundora and colleagues ${ }^{28}$. Inoculums were prepared as follows: $S$. cerevisiae was grown in $100 \mathrm{~mL}$ of PPR hydrolysate(acid or enzyme) for $16 \mathrm{~h}$ at $30^{\circ} \mathrm{C}$ on a rotary shaker at $100 \mathrm{rpm}$ (Stuart, France). Further, pre-cultures were centrifuged $\left(10 \mathrm{~min}\right.$ at $\left.5000 \mathrm{~g}, 4^{\circ} \mathrm{C}\right)$ and cell pellets were re-suspended in $0.9 \%$ sterile saline and used as inoculum. Batch cultures were conducted in $1.8 \mathrm{~L}$ bioreactor (Infors HT, Switzerland) containing $0.5 \mathrm{~L}$ of culture medium inoculated with $15 \%(\mathrm{w} / \mathrm{v})$ of $S$. cerevisiae pre-culture. Cultures were incubated at $30^{\circ} \mathrm{C}$ at a stirring speed of $250 \mathrm{rpm}$ and air flow of $0.6 \mathrm{NL} / \mathrm{min}$. The $\mathrm{pH}$ was adjusted to 5 with $\mathrm{HCl}$ (1 M) and $\mathrm{NaOH}(1 \mathrm{M})$. Samples were withdrawn at regular intervals and centrifuged at $13800 \mathrm{~g}$ for $5 \mathrm{~min}$ at $4^{\circ} \mathrm{C}$. The supernatant was analyzed for the content of reducing sugars and ethanol. All experiments were performed in duplicates and results are expressed as mean \pm standard deviation.

\subsection{Analytical methods}

2.8.1 Determination of the contents of cellulose, hemicellulose, starch, and lignin

The contents of cellulose, hemicellulose, and lignin in untreated and pretreated PPR samples were determined as described earlier ${ }^{29}$. Substrate $(10 \mathrm{~g})$ was dispersed in $100 \mathrm{~mL}$ $\mathrm{H}_{2} \mathrm{SO}_{4}$ solution $(72 \%, \mathrm{v} / \mathrm{v})$ and boiled for $4.5 \mathrm{~h}$ to ensure a total hydrolysis of cellulose and hemicellulose. The filtrate obtained after the acid treatment was analyzed for the content of glucose and reducing sugars by a glucose oxidase/peroxidase assay kit (Biomaghreb, Tunisia)and dinitrosalisylic acid method ${ }^{30}$, respectively. The residual solid fraction was dried at $105^{\circ} \mathrm{C}$ for $24 \mathrm{~h}$, weighed, and referred as $\mathrm{R}_{1}$ before being heated at $600^{\circ} \mathrm{C}$ for $5 \mathrm{~h}$. After cooling, it was weighed and referred as $\mathrm{R}_{2}$.

Cellulose content in treated and untreated PPR was determined using the following equation (Eq2)

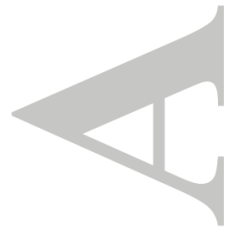

$$
\%(\mathrm{w} / \mathrm{w}) \text { cellulose content }=(0.9 / 0.96) \times \mathrm{G} \times\left(\mathrm{V} / \mathrm{D}_{\mathrm{W}}\right) \times 100
$$


where 0.9 coefficient is the ratio of molecular weights of cellulose to glucose, 0.96 coefficient is the saccharification yield, $\mathrm{G}$ is the glucose concentration $(\mathrm{g} / \mathrm{L}), \mathrm{V}$ is the total volume of sugar solution (L), and $\mathrm{D}_{\mathrm{W}}$ is the dry weight of the PPR samples.

Hemicellulose content in treated and untreated PPR was determined using the following equation $(\mathrm{Eq} 3)$

$$
\%(\mathrm{w} / \mathrm{w}) \text { hemicellulose content }=(0.88 / 0.93) \times\left(\mathrm{R}_{\mathrm{S}}-\mathrm{G}\right) \times(\mathrm{V} / \mathrm{M}) \times 100
$$

where 0.88 coefficient is the ratio of molecular weights of hemicellulose and the hexose monomer, the 0.96 coefficient is the conversion yield of xylane to xylose, $G$ is the glucose concentration $(g / L), R_{S}$ the concentration of reducing sugars $(g / L), V$ is the total volume of sugar solution (L), and $\mathrm{D}_{\mathrm{W}}$ is the dry weight of the PPR samples.

Lignin content in treated and untreated PPR was calculated using the following equation $(\mathrm{Eq} 4)$

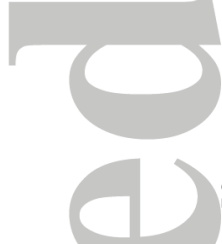

$$
\%(\mathrm{w} / \mathrm{w}) \text { lignin content }=\left(\mathrm{R}_{1}-\mathrm{R}_{2}\right) \times 100
$$

Starch content of untreated and pretreated PPR was determined according to a previously described method ${ }^{31}$. Substrate $(0.5 \mathrm{~g})$ was dispersed in $100 \mathrm{~mL}$ of boiling distilled water and the solution was cooled at room temperature and filtered. To $10 \mathrm{~mL}$ of the filtrate, 1 $\mathrm{mL}$ of iodine solution $(0.1 \mathrm{M})$ was added, and after 1minute, $2 \mathrm{~mL}$ of $20 \%(\mathrm{w} / \mathrm{v})$ acetate potassium solution was added. The starch iodide complex coagulated in about 5 min. Further, the precipitate was filtered, washed with $200 \mathrm{~mL}$ of $80 \%$ ethanol before drying in the oven at $100^{\circ} \mathrm{C}$ for $12 \mathrm{~h}$, and weighed.

\subsubsection{Fourier transformed infrared spectroscopy analysis}

Fourier transformed infrared spectroscopy (FTIR) was performed on a Perkin Elmer Spectrum -Two Spectrometer. A total of 25 cumulative scans were recorded per sample in the range from 4000 to $400 \mathrm{~cm}^{-1}$ with the resolution of $4 \mathrm{~cm}^{-1}$.

\subsubsection{Morphological and structural analysis by scanning electron microscopy}


Morphological and structural analysis of untreated and pretreated PPR was performed using a Quanta 200 FEI (Hillsboro, Oregon) scanning electron microscope (SEM). Samples used in this analysis were fixed on an aluminum support and then subjected to the gold metallization process.

2.8.4 Determination of reducing sugars

The concentration of reducing sugars in different samples was determined according to a previously described method ${ }^{30}$.

\subsubsection{Calculation of hydrolysis yield}

Hydrolysis yield was determined as previously described ${ }^{32}$ (Eq5):

Hydrolysisyield(\%)

$$
=\frac{\text { reducingsugarsformed } \times 0.9}{\text { totalcarbohydratecontent }(\text { starch, cellulose, hemicellulose) insubstrate }} \times 100
$$

\subsubsection{Determination of hydroxymethylfurfural}

Hydroxymethyl furfural (HMF) was determined in acid and enzyme hydrolysates according to a previously described method ${ }^{33}$. Analysis was carried out by Knauer highperformance liquid chromatography (HPLC) system equipped with $\mathrm{C} 18(4 * 250 \mathrm{~mm}, 8 \mu \mathrm{m}$, Phenomenex) column. The analysis was performed at a flow rate of $1 \mathrm{~mL} / \mathrm{min}$ and at $30^{\circ} \mathrm{C}$ with $5 \%$ acetic acid $(\mathrm{w} / \mathrm{v})$ in water/methanol (80:20) as the mobile phase. The detection of HMF was performed by UV detector (Knauer) at $285 \mathrm{~nm}$.

\subsubsection{Determination of ethanol content}

The ethanol concentration was determined according to the method described earlier ${ }^{27}$. Analysis was performed using a Knauer HPLC system equipped with a refractive index detector (Knauer). REZEX ROA $(7.8 \times 300 \mathrm{~mm}, 8 \mu \mathrm{m}$, Phenomenex $)$ was used as the HPLC column. The temperature of the column was adjusted to $65^{\circ} \mathrm{C} . \mathrm{H}_{2} \mathrm{SO}_{4}(0.025 \mathrm{~N})$ was used as mobile phase at a flow rate of $0.6 \mathrm{~mL} / \mathrm{min}$.

\section{Results and Discussion}




\subsection{Characterization of untreated and pretreated PPR}

In this study, three pretreatment methods were investigated with the aim to determine the optimum conditions that can maximize enzyme hydrolysis of PPR. For that purpose, PPR was first dispersed either in water, $1 \%(\mathrm{v} / \mathrm{v}) \mathrm{H}_{2} \mathrm{SO}_{4}$, or $1 \%(\mathrm{w} / \mathrm{v}) \mathrm{NaOH}$, followed by incubation at $121^{\circ} \mathrm{C}$ for $30 \mathrm{~min}$. Modifications in the substrate structure and chemical composition after each physicochemical pretreatment were evaluated by FTIR, SEM; the determination of contents of cellulose, hemicellulose, starch and lignin was done after each pretreatment and compared to those of untreated PPR.
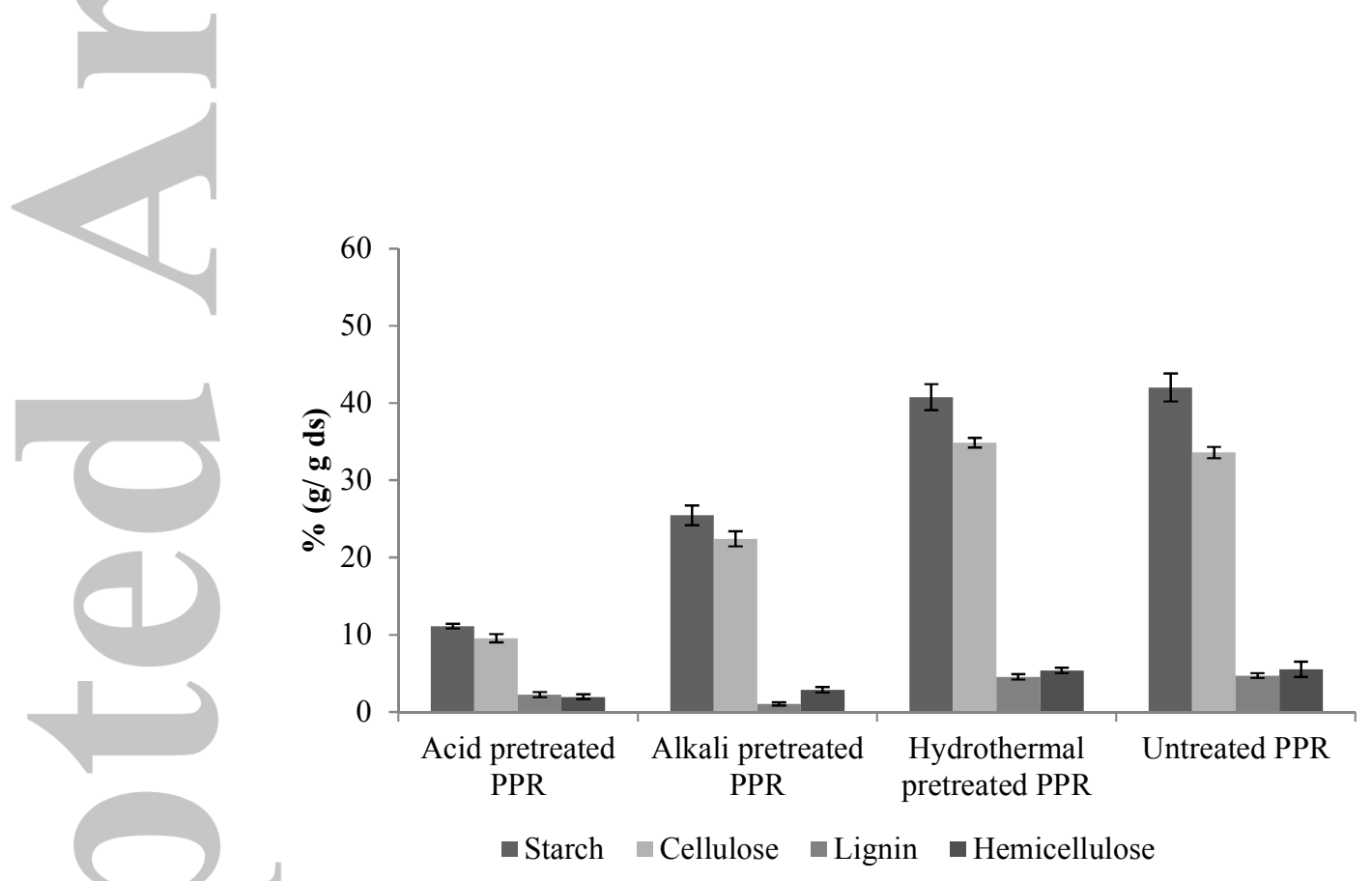

Figure.1. Contents of cellulose, starch and lignin in untreated and pretreated Potato Peels Residues

As shown in Figure 1, the contents of starch, cellulose, lignin, and hemicellulose in PPR are equal to $42 \% 33.5 \%, 4.7 \%$, and $5.5 \%$, respectively. After alkaline pretreatment, they decreased to $25.4 \%, 22.4 \%, 1.1 \%$, and $2.8 \%$, respectively, whereas upon acid pretreatment, they decreased to $10.1 \% 20 \%, 2.2 \%$, and $1.9 \%$, respectively. This indicates that $76 \%$ starch, $40.2 \%$ cellulose, $52.1 \%$ lignin, and $95.3 \%$ hemicellulose present in untreated PPR could be degraded to $10.1 \% 20 \%, 2.2 \%$, and $1.9 \%$, respectively, by acid pretreatment. In contrast, 
hydrothermally pretreated PPR composition did not show significant modification as compared to that of untreated PPR and the content of starch, cellulose, lignin, and hemicellulose contents were noted to be $40.7 \%, 34.8 \%, 4.5 \%$, and $5.4 \%$, respectively. Hydrothermal pretreatment modifies physical structure of the lignocellulosic substrate while minimizing its degradation, which differs from acid and alkali pretreatments. Hydrothermal pretreatment is known to hydrate the crystalline structure of cellulose and convert it to an amorphous form which is more accessible for enzyme digestion without its degradation into monomers of glucose ${ }^{34}$. Moreover, hydrothermal pretreatment maximized the solubilization of starch while preventing its degradation into sugar monomers ${ }^{35}$. Conversely, under acid or alkali conditions, polysaccharides could be partially degraded ${ }^{36}$.

The comparison of FTIR spectra between pretreated PPR and untreated PPR highlighted that pretreatment induces some specific structural modifications in PPR(Figure 2).
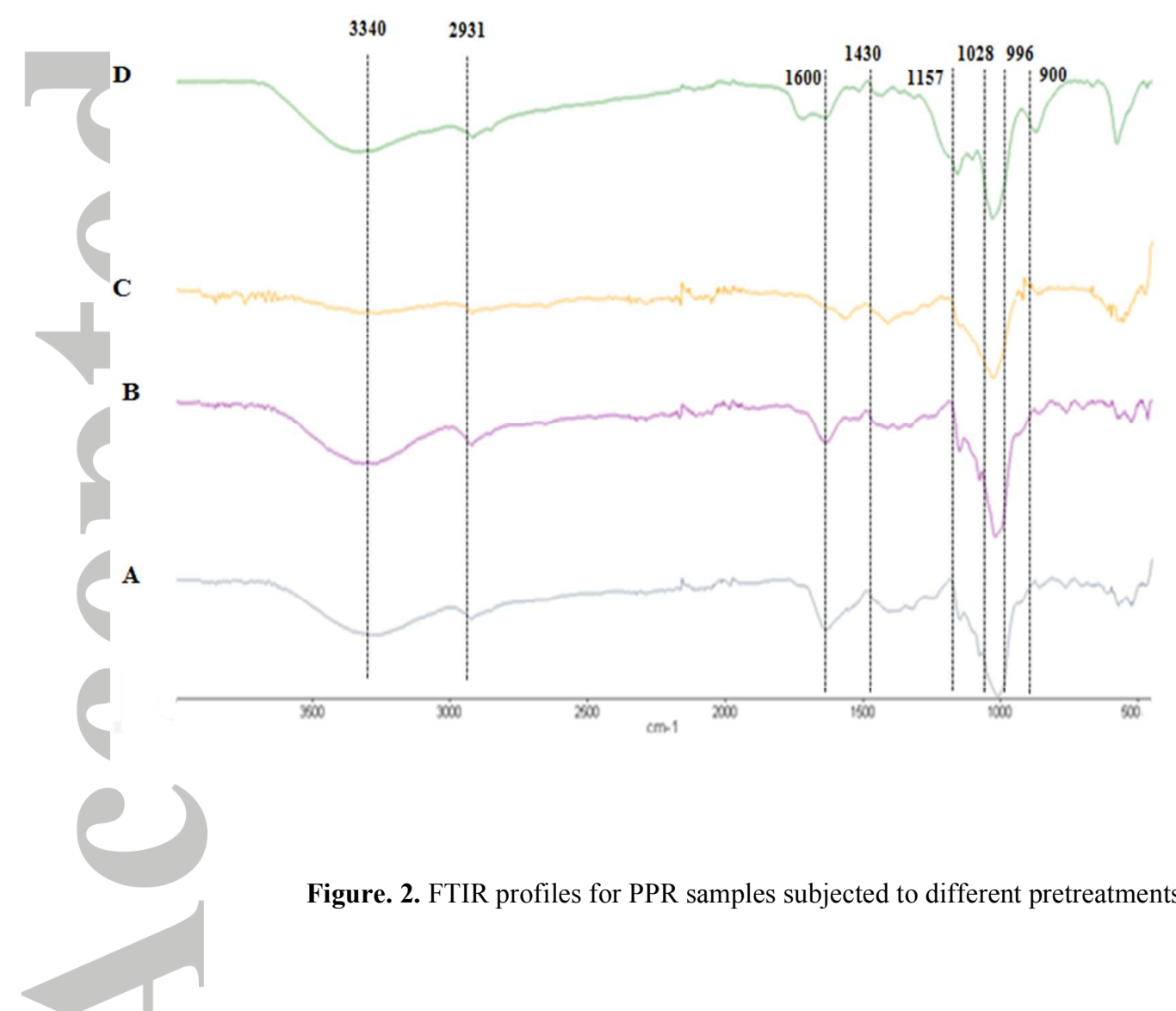

Figure. 2. FTIR profiles for PPR samples subjected to different pretreatments

(A) untreated PPR; (B) hydrothermal pretreated PPR; (C) alkali pretreated PPR; (D) acid treated PPR 
The intensity of the characteristic hemicellulose band at $1028 \mathrm{~cm}^{-1}$ decreased in alkali and acid pretreated PPR, indicating that hemicellulose was partially hydrolyzed during these two pretreatments and, more intensively, under acid conditions. The intensity of the peak at $3340 \mathrm{~cm}^{-1}$ attributed to $\mathrm{OH}$ group in lignin chain decreased more considerably upon alkali treatment than the hydrothermal and acid treatment ${ }^{37}$. Alkali treatment is known to remove lignin fraction ${ }^{38}$. The intensity of the peak at $1157 \mathrm{~cm}^{-1}$ attributed to $\mathrm{C}-\mathrm{O}-\mathrm{C}$ bond in the cellulose chain decreased more considerably upon acid treatment than alkali pretreatment indicating a partial degradation of cellulose ${ }^{39}$. However, the intensity of the same peak does not show a remarkable decrease in the case of hydrothermally pretreated PPR in comparison with untreated PPR. Peaks at $1430 \mathrm{~cm}^{-1}$ and $900 \mathrm{~cm}^{-1}$ were attributed to "crystalline" and "amorphous" forms of cellulose, respectively. The ratio of absorbance $\left(\mathrm{A}_{1430} / \mathrm{A}_{900}\right)$ could be defined as an empirical "crystallinity index" ${ }^{40}$. The intensity of band at $1430 \mathrm{~cm}^{-1}$ decreased slightly in hydrothermal and alkali pretreated PPR, and more considerably, in acid pretreated PPR. In contrast, the intensity of band at $900 \mathrm{~cm}^{-1}$ increased in alkali and hydrothermally pretreated PPR as compared to that in untreated PPR. In the case of acid pretreated PPR, the same peak shifted to a higher wavenumber (about $5 \mathrm{~cm}^{-1}$ ) and showed a remarkable increase in intensity. Hence, it can be reported that the crystallinity index of cellulose decreased in all pretreated samples, especially, after acid pretreatment. The intensity of peaks at $2931 \mathrm{~cm}^{-1}$ and $1600 \mathrm{~cm}^{-1}$ attributed to methyl group and carbonyl groups, respectively, in the starch chain decreased slightly, in the case of hydrothermally pretreated PPR and more considerably in the case of alkali and acid pretreated PPR ${ }^{41}$. Moreover, the band at $1000 \mathrm{~cm}^{-1}$ splits into two bands at $996 \mathrm{~cm}^{-1}$ and $1017 \mathrm{~cm}^{-1}$ in the case of hydrothermally pretreated PPR. Such a split is correlated to a change from native to gelatinized form of $\operatorname{starch}^{41}$.

Figure 3 (A, B, C, and D) shows SEM images (morphological and structural surfaces) of PPR samples subjected to different pretreatments. The untreated PPR sample shows an even, regular, and smooth surface which indicates that the surface structure is rigid (Figure 3A). In addition, the sample is covered by starch on the surface. Figure $3 \mathrm{~B}$, relative to hydrothermally pretreated PPR, shows the presence of small holes on surfaces. However, the surface was still observed to be rigid and covered by starch. Figure $3 \mathrm{C}$ represents the structure of alkali pretreated PPR sample. It was observed that the substrate presents an uneven and broken surface. The fragments were detached from the initial surface in addition to a partial removal of starch from the surface. As shown in Figure 3D, a fragile and broken surface with total 
removal of starch from surface could be observed after acid pretreatment of PPR. These results highlight that different pretreatments lead to some modifications in the structure and chemical composition of PPR. These modifications would either favor or hinder enzyme hydrolysis.
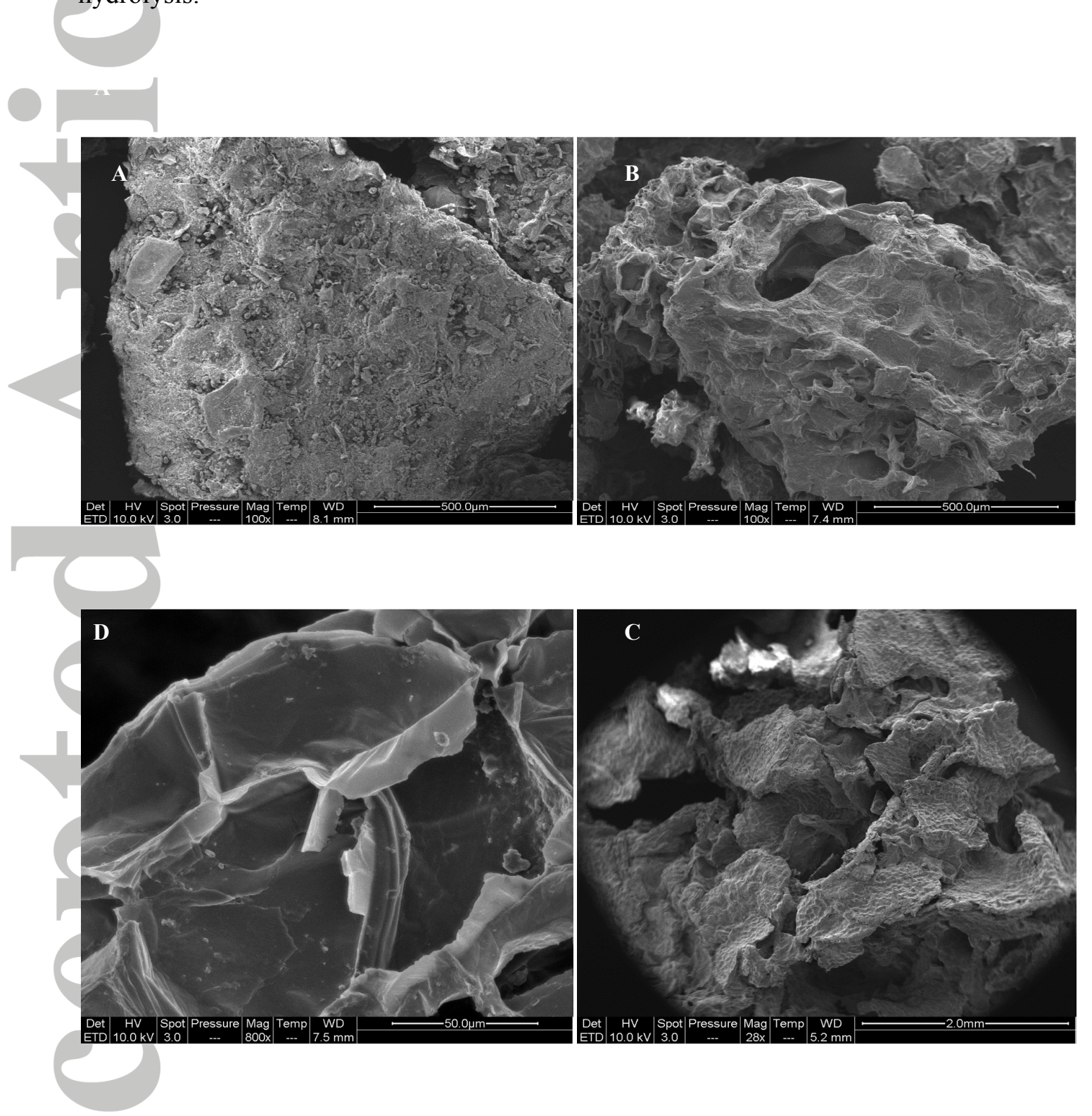

Figure. 3.SEM images of potato peels residues

(A) untreated PPR; (B) hydrothermal pretreated PPR; (C) alkali pretreated PPR; (D) acid treated PPR

3.2 Effect of different pretreatments on enzyme hydrolysis of PPR 
The concentration of reducing sugars and saccharification yields obtained for PPR samples subjected to different pretreatments are shown in Table 1.

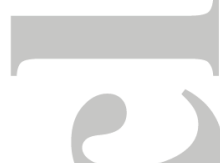

Table 1. Summary of average yield saccharification obtained for different PPR samples

\begin{tabular}{|c|c|c|}
\hline Sample & $\begin{array}{c}\text { Reducing sugars } \\
\text { concentration }(\mathrm{g} / \mathrm{L})\end{array}$ & Saccharification yield (\%) \\
\hline Untreated PPR & $18.5 \pm 0.5$ & 20 \\
\hline Hydrothermal pretreated PPR & $57.8 \pm 2.1$ & 63 \\
\hline Alkali pretreated PPR & $33.6 \pm 1.5$ & 38 \\
\hline Acid pretreated PPR & $15.3 \pm 0.43$ & 37 \\
\hline
\end{tabular}

The concentration of reducing sugars released by enzyme hydrolysis was significantly different depending on the substrate used. The highest yield of reducing sugars $(57.8 \pm 2.1 \mathrm{~g} / \mathrm{L})$ was obtained from hydrothermally pretreated PPR followed by alkali pretreated PPR $(33.6 \pm 1.5 \mathrm{~g} / \mathrm{L})$, and the lowest yield was obtained from acid pretreated PPR $(15.3 \pm 0.43 \mathrm{~g} / \mathrm{L})$. Moreover, the highest yield of hydrolysis (63\%) was obtained from hydrothermally pretreated PPR followed by alkali pretreated PPR (58\%) and the lowest yield of hydrolysis was obtained from untreated PPR (20\%). Therefore, the pretreatment method has a significant effect on the yield of reducing sugars generated by enzyme hydrolysis. We have shown that pretreatment modifies both the structure and composition of the substrate. Consequently, these modifications could affect the enzymatic saccharification. Hydrothermal pretreatment seems to be the most appropriate method for PPR pretreatment prior to enzymatic saccharification. Moreover, this method does not require the utilization of chemicals, such as acid or alkali, and thus lead to a more eco-friendly process. In subsequent experiments, hydrothermal method was used for the pretreatment of PPR before enzyme hydrolysis. The effects of pretreatment methods on hydrolysis yield were extensively discussed in the literature. However, no standard method could be defined since they are specific to each biomass studied. Wang and colleagues $^{42}$ investigated the effect of two different alkali pretreatments (i.e., $\mathrm{NaOH}$ and calcium hydroxide $(\mathrm{CaOH}))$ on the enzyme hydrolysis of Coastal Bermudagrass. They report that $\mathrm{NaOH}$ pretreatment was more efficient than $\mathrm{CaOH}$ to improve the yield of reducing sugars. In the same line, Sukumaran and colleagues ${ }^{43}$ reported that alkali pretreatment of rice 
straw and water hyacinth biomasses resulted in a higher yield of reducing sugars than that obtained by acid pretreatment.

\subsection{Optimization of enzyme hydrolysis of hydrothermally pretreated PPR by Box-Behnken} design

To optimize the enzyme hydrolysis step, three level four-factorial BBD was applied to examine parameters that influence the yield of reducing sugars from the enzyme hydrolysis of hydrothermally pretreated PPR. Temperature, $\mathrm{pH}$, substrate concentration, and surfactant concentration were selected as variable input parameters. The concentration of reducing sugars was used as the output parameter. Experimental results as a function of temperature, $\mathrm{pH}$, surfactant concentration, and substrate concentration are shown in Table 2. Maximum concentration of reducing sugars $(77.1 \mathrm{~g} / \mathrm{L})$ was observed at temperature of $45^{\circ} \mathrm{C}, \mathrm{pH}$ of 5 , substrate concentration of $10 \%$, and surfactant concentration of $0.5 \%$.

Table 2. Reducing sugars concentration generated from hydrothermal pretreated PPR under different enzymatic hydrolysis conditions

\begin{tabular}{|c|c|c|c|c|c|c|}
\hline Run Order & $\mathrm{V} 1$ & $\mathrm{~V} 2$ & $\mathrm{~V} 3$ & $\mathrm{~V} 4$ & $\begin{array}{r}\text { Reducing sugars } \\
\text { concentration }\end{array}$ & $\begin{array}{c}\text { Hydrolysis } \\
\text { yield (\%) }\end{array}$ \\
\hline 1 & 45 & 5 & 2 & 0.5 & 37.1 & 41 \\
\hline 2 & 30 & 6.5 & 2 & 0.5 & 17.8 & 20 \\
\hline 3 & 45 & 6.5 & 10 & 0 & 53.1 & 58 \\
\hline 4 & 60 & 6.5 & 6 & 0 & 40.5 & 45 \\
\hline 5 & 45 & 6.5 & 6 & 0.5 & 43.1 & 47 \\
\hline 6 & 45 & 8 & 6 & 1 & 9.3 & 10 \\
\hline 7 & 45 & 6.5 & 6 & 0.5 & 41.1 & 45 \\
\hline 8 & 60 & 6.5 & 2 & 0.5 & 16.6 & 6 \\
\hline 9 & 30 & 5 & 6 & 0.5 & 5.3 & 21 \\
\hline 10 & 45 & 8 & 6 & 0 & 18.8 & 2 \\
\hline 11 & 45 & 8 & 2 & 0.5 & 1.4 & 49 \\
\hline 12 & 30 & 6.5 & 6 & 1 & 2.1 & 24.3 \\
\hline 13 & 45 & 6.5 & 2 & 1 & 44.8 & 27 \\
\hline 14 & 60 & 6.5 & 10 & 0.5 & & 2 \\
\hline
\end{tabular}




\begin{tabular}{|c|c|c|c|c|c|c|}
\hline 15 & 45 & 6.5 & 2 & 0 & 31.1 & 34 \\
\hline 16 & 30 & 6.5 & 10 & 0.5 & 4.7 & 5 \\
\hline 17 & 45 & 6.5 & 6 & 0 & 58.5 & 64 \\
\hline 18 & 60 & 8 & 6 & 0.5 & 16.7 & 18 \\
\hline 19 & 30 & 6.5 & 6 & 0 & 1.1 & 1 \\
\hline 20 & 45 & 6.5 & 6 & 0.5 & 47.6 & 52 \\
\hline 21 & 30 & 8 & 6 & 0.5 & 1.8 & 2 \\
\hline 22 & 45 & 5 & 10 & 0.5 & 77.1 & 84 \\
\hline 23 & 60 & 5 & 6 & 0.5 & 39.2 & 43 \\
\hline 24 & 45 & 8 & 10 & 0.5 & 13.4 & 15 \\
\hline 25 & 45 & 5 & 6 & 1 & 63.1 & 69 \\
\hline 26 & 45 & 6.5 & 10 & 1 & 60.4 & 66 \\
\hline 27 & 60 & 6.5 & 6 & 1 & 37.5 & 41 \\
\hline
\end{tabular}

The regression equation representing the correlation between the concentration of reducing sugars and the variables could be written as follows (Eq6):

Yield of reducing sugars $(\mathrm{g} / \mathrm{L})=-308.894+9.83 \mathrm{~V}_{1}+52.33 \mathrm{~V}_{2}+2.91 \mathrm{~V}_{3}+22.32 \mathrm{~V}_{4}-0.09$ $\mathrm{V}_{1}^{2}-4.59 \mathrm{~V}_{2}^{2}-0.13 \mathrm{~V}_{3}^{2}-0.89 \mathrm{~V}_{4}^{2}-0.25 \mathrm{~V}_{1} \mathrm{~V}_{2}+0.17 \mathrm{~V}_{1} \mathrm{~V}_{3}-0.13 \mathrm{~V}_{1} \mathrm{~V}_{4}-1.52 \mathrm{~V}_{2} \mathrm{~V}_{3}-5.69$ $\mathrm{V}_{2} \mathrm{~V}_{4}+1.75 \mathrm{~V}_{3} \mathrm{~V}_{4}$

where $\mathrm{V}_{1}, \mathrm{~V}_{2}, \mathrm{~V}_{3}$, and $\mathrm{V}_{4}$ are temperature, $\mathrm{pH}$, substrate concentration, and surfactant concentration, respectively.

The analysis of the $p$-value of each variable suggests that surfactant concentration is not a significant parameter $(p>0.05)$. In addition, only the quadratic variables, $\mathrm{V}_{1}$ and $\mathrm{V} 2$, and the interactions between $\mathrm{V}_{1}$ and $\mathrm{V}_{3}, \mathrm{~V}_{2}$ and $\mathrm{V}_{3}$ were found to be significant in the model $(p<$ 0.05).Hence, a statistically significant model taking into account only the significant variables could be written as follows (Eq7):

$$
\begin{gathered}
\mathrm{Y}=-291.7+9.65 \mathrm{~V}_{1}+50.4 \mathrm{~V}_{2}+2.17 \mathrm{~V}_{3}-0.1069 \mathrm{~V}_{1} \mathrm{~V}_{1}-6.09 \mathrm{~V}_{2} \mathrm{~V}_{2}+0.1719 \mathrm{~V}_{1} \mathrm{~V}_{3}-1.526 \\
\mathrm{~V}_{2} \mathrm{~V}_{3}
\end{gathered}
$$


The summary of the analysis of variance (ANOVA) and the $F$-test for the selected quadratic model is presented in Table 3. The low $p$-value shows the good fit of the quadratic model. The correlation coefficient $\left(\mathrm{R}^{2}\right)$ was calculated to be 0.91 , indicating that there was good agreement between predicted and experimental concentrations of reducing sugars under different conditions of $\mathrm{pH}$, temperature, and substrate concentration.

Table 3. ANOVA of fitted quadratic model for enzymatic hydrolysis of hydrothermal pretreated PPR

\begin{tabular}{|c|c|c|}
\hline Source & $F$ statistic & $p$-value \\
\hline Model & 26.33 & 0.000 \\
\hline $\mathrm{V}_{1}$ & 45.64 & 0.000 \\
\hline $\mathrm{V}_{2}$ & 78.09 & 0.000 \\
\hline $\mathrm{V}_{3}$ & 22.99 & 0.000 \\
\hline $\mathrm{V}_{1} \mathrm{~V}_{1}$ & 56.79 & 0.000 \\
\hline $\mathrm{V}_{2} \mathrm{~V}_{2}$ & 8.89 & 0.008 \\
\hline $\mathrm{V}_{1} \mathrm{~V}_{3}$ & 7.20 & 0.015 \\
\hline $\mathrm{V}_{2} \mathrm{~V}_{3}$ & 3.94 & 0.063 \\
\hline
\end{tabular}

In contrast to our report, many reports underline the importance of surfactants to enhance the enzyme hydrolysis of biomass. The mechanism of this phenomenon has not been established but the effect of surfactant on biomass hydrolysis may be attributed to its ability of adsorption to lignin, thus preventing unproductive binding of the hydrolytic enzymes to the latter and resulting in increased hydrolysis yield (17). Shindu and colleagues ${ }^{44}$ demonstrated that the utilization of surfactant such as Tween 80 enhances the enzyme saccharification of sugarcane bagasse. Moreover, some researchers demonstrated that using Tween 80increased the hydrolysis yield of pretreated wheat $\operatorname{straw}^{20}$. These contradictory observations could be related to the nature of the substrate hydrolyzed. In fact, Kim and colleagues ${ }^{45}$ reported that the effect of surfactant on the biomass digestibility is highly dependent on the biomass considered. They reported that surfactant (Tween 80) increased the enzyme hydrolysis of untreated newspaper significantly, whereas, its effect on the hydrolysis of pretreated newspaper was marginal. 
Surface plots representing the interaction between a pair of significant factors from Eq6 on hydrolysis of pretreated PPR were used to highlight the interaction between variables and to determine the optimum value of each factor that led to maximum hydrolysis yields.

A
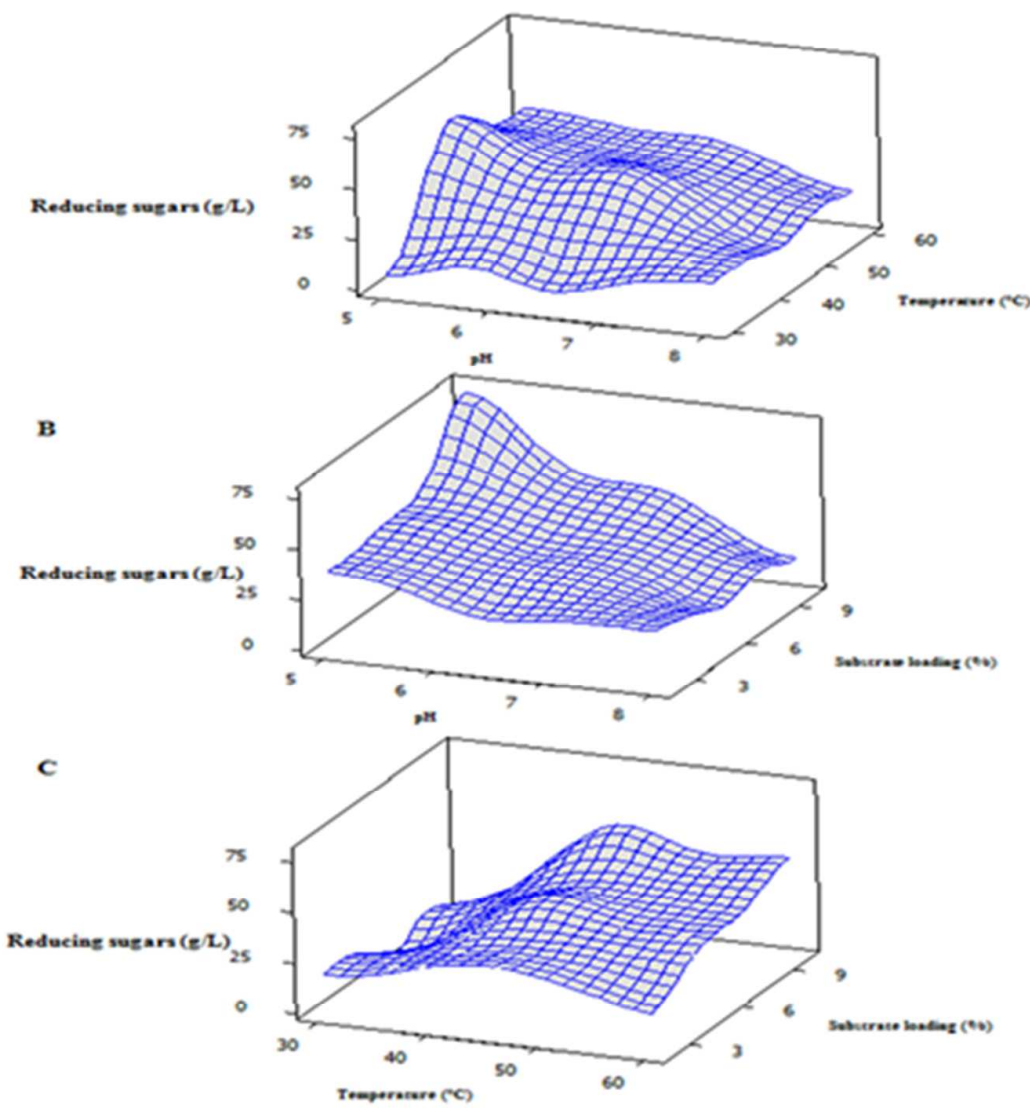

Figure. 4. Surface plots described by the proposed model showing the interactive effects of various parameters on reducing sugars production after enzymatic hydrolysis of hydrothermal pretreated potato peels residues

A. Effect of $\mathrm{pH}$ and temperature on reducing sugars concentration; B. Effect of $\mathrm{pH}$ and substrate loading on reducing sugars concentration; C. Effect of temperature and substrate concentration on reducing sugars concentration.

The effect of interaction between $\mathrm{pH}$ and temperature on the concentration of reducing sugars is shown in Figure 4A. At low temperature, the concentration of reducing sugars was 
low. Significant improvement in content of reducing sugars was noted by increasing the temperature. When the temperature was set at middle level $\left(45^{\circ} \mathrm{C}\right)$ and $\mathrm{pH}$ was set at low level (5), the concentration of reducing sugars reached maximum level $(77 \mathrm{~g} / \mathrm{L})$. However, beyond $45^{\circ} \mathrm{C}$, there was a reduction in the concentration of reducing sugars. Temperature is known to be a key factor affecting enzymatic reaction. High temperature decreases the hydrolysis yield due to the inactivation of enzymes ${ }^{46}$.

The effects of $\mathrm{pH}$ and substrate concentration on the hydrolysis of PPR are shown in Figure 4B. At low substrate concentration (2\%) and pH higher than 5, the content of reducing sugars decreased significantly. $\mathrm{pH}$ is known as an important factor that significantly affects the enzyme activity ${ }^{46}$. Similar to substrate concentration, the yield of reducing sugars increased with increasing substrate concentration. This surface plot shows that low $\mathrm{pH}$ (5) and high substrate concentration (10\%), yielded maximum concentration of reducing sugars.

The effects of temperature and substrate concentration on the hydrolysis of PPR are shown in Figure $4 \mathrm{C}$. High yields of reducing sugars are obtained for mild temperature $\left(45^{\circ} \mathrm{C}\right)$ and high substrate concentration (20\%). Substrate concentration is considered as a key factor that affects the enzymatic reaction ${ }^{20}$. It worth mentioning that these surface plots present local maxima. They are probably due to a specific combined effect of the tested parameter on enzymatic activity. However, we focus only on global maxima in this study.

In order to verify the validity of the model, three experiments were conducted within the range of experimental design. The concentration of reducing sugars was determined and compared with the predicted values (Table 4). In all experiments, the experimental data were in good agreement with the predicted values. Therefore, the empirical model developed was reasonably accurate and presents an efficient tool to optimize the conditions for enzyme hydrolysis of hydrothermally pretreated PPR.

\section{Table 4. Experimental and model predicted values for reducing sugars concentration at} different combinations of variables

\begin{tabular}{|c|c|c|c|c|}
\hline \multicolumn{5}{|c|}{ different combinations of variables } \\
\hline Substrate & & Temperature & \multicolumn{2}{|c|}{ Reducing sugar yield $(\mathrm{g} / \mathrm{L})$} \\
\cline { 4 - 5 } concentratio & $\mathrm{pH}$ & $\left({ }^{\circ} \mathrm{C}\right)$ & Predicted values & Experimental values \\
\hline $\mathrm{n} \%(\mathrm{w} / \mathrm{v})$ & & & 31.2 & 38.7 \\
\hline 8 & 5.5 & 45 & & \\
\hline
\end{tabular}




\begin{tabular}{|l|l|l|l|l|}
\hline 2 & 5 & 45 & 53.9 & 57.3 \\
\hline 10 & 6 & 35 & 16.7 & 14.5 \\
\hline
\end{tabular}

\subsection{Comparison between acid and enzyme hydrolysis in ethanol fermentation}

In order to evaluate the efficiency of hydrolysis of PPR with the crude enzyme mixture, PPR was hydrolyzed by acid solution. Acid hydrolysis of lignocellulosic biomass is widely used to ensure the conversion of complex carbohydrates into monomers of sugars ${ }^{47}$. Acid and enzyme hydrolysates were compared in terms of reducing sugars generated, HMF contents, and ethanol yield after fermentation step.

As shown in Table 5, the total amount of reducing sugars obtained after acid and enzyme hydrolysis was slightly different. Nevertheless, ethanol yield was higher in the case of enzyme hydrolysate $(0.26)$ than that in acid hydrolysate $(0.17)$. The lowest consumption of reducing sugars in the medium prepared from acid PPR hydrolysate suggested the existence of inhibitory metabolites in the medium.

Table 5. Characterization of acid and enzymatic hydrolyzates before and after fermentation

\begin{tabular}{|l|c|c|}
\hline & Acid hydrolyzate & $\begin{array}{c}\text { Enzymatic } \\
\text { hydrolyzate }\end{array}$ \\
\hline Reducing sugars concentration (g/L) & $80 \pm 3.6$ & $77 \pm 2.1$ \\
\hline Reducing sugars consumption (\%) & 40 & 98 \\
\hline $\begin{array}{l}\text { Ethanol production (g/L) } \\
\text { Ethanol yield (g/ g of consumed reducing } \\
\text { sugars) }\end{array}$ & $5.7 \pm 0.5$ & $20.08 \pm 0.36$ \\
\hline HMF concentration (g/L) & 0.17 & 0.26 \\
\hline
\end{tabular}

The inhibition of the fermentation when acid hydrolysate was used could be explained by the presence of HMF $(1.7 \mathrm{~g} / \mathrm{L})$ in the medium, which is recognized as a strong inhibitor of yeast growth $^{48}$. HMF results from the breakdown of hexoses during acid hydrolysis and could exert a strong inhibitory effect on alcohol dehydrogenase and aldehyde dehydrogenase ${ }^{49}$. It has been reported that HMF at concentration higher than $0.5 \mathrm{~g} / \mathrm{L}$ results in decreased glucose consumption and ethanol production yield ${ }^{50}$. 


\subsection{Effect of nitrogen supplementation on ethanol fermentation}

Enzyme hydrolysates of hydrothermally pretreated PPR with or without nitrogen supplementation were used as substrate for ethanol production.

Table 6. Ethanol production and yield during fermentation of $S$. cerevisiae in the presence of different nitrogen sources

\begin{tabular}{|l|c|c|}
\hline Nitrogen source & $\begin{array}{c}\text { Ethanol concentration } \\
(\mathrm{g} / \mathrm{L})\end{array}$ & $\begin{array}{c}\text { Ethanol yield } \\
(\mathrm{g} / \mathrm{g} \text { of reducing sugars })\end{array}$ \\
\hline Ammonium sulfate & $30 \pm 0.50$ & 0.40 \\
\hline Peptone & $20.24 \pm 0.24$ & 0.27 \\
\hline None & $20.08 \pm 0.36$ & 0.26 \\
\hline
\end{tabular}

As shown in Table 6, peptone supplementation led to a slight increase in ethanol production as compared to that in the non-supplemented medium. However, a significant improvement of ethanol production was observed in the medium supplemented with ammonium sulfate. The yield of ethanol increased from $0.26 \mathrm{~g} / \mathrm{g}$ in the control medium (without nitrogen addition) to $0.4 \mathrm{~g} / \mathrm{g}$ in the ammonium sulfate-supplemented medium. Currently, the supplementation of the culture medium with inorganic nitrogen is known to boost fermentation metabolism in yeast cultures ${ }^{27,}{ }^{51}$. Limited reports on bioethanol production from potato waste are published. Arapoglou and colleagues ${ }^{7}$ revealed that the hydrolysis of potato peel waste with a combination of three commercial enzymes released only $18.5 \mathrm{~g} / \mathrm{L}$ reducing sugars and produced $7.6 \mathrm{~g} / \mathrm{L}$ of ethanol. Similarly, Khawla and colleagues ${ }^{26}$ used a combined mixture composed of commercial amyloglucosidase and an onsite produced amylase UEB-S for the hydrolysis of potato peel residues. Under optimal conditions of hydrolysis and fermentation, $69 \mathrm{~g} / \mathrm{L}$ of reducing sugars and $21 \mathrm{~g} / \mathrm{L}$ of ethanol were released.

A large number of authors have studied bioethanol production from different feedstocks. In their study, Kima and colleagues ${ }^{52}$ reported that enzymatic hydrolysis of barley hull by xylanase and cellulase released $47 \mathrm{~g} / \mathrm{L}$ of reducing sugars and $24.1 \mathrm{~g} / \mathrm{L}$ of ethanol. In their research, Gouvea and colleagues ${ }^{53}$ reported that batch fermentation of coffee husks released $13.6 \mathrm{~g} / \mathrm{L}$ of ethanol. Compared to these reports, the amount of ethanol reported here $(30 \mathrm{~g} / \mathrm{L})$ is higher. 


\section{CONCLUSION}

The main limitation to the utilization of enzymes in bioethanol production is the production cost. Hence, any strategy that can lower the production cost encourages their application at the industrial scale for bioethanol production. In this study, we proposed a process for bioethanol production that uses PPR as feedstock. The process involves the utilization of complex hydrolytic enzymes produced through solid-state fermentation based on a co-culture of $A$. niger and $T$. reesei using PPR as a substrate and solid support. The choice of the pretreatment method can considerably influence the efficiency of the hydrolysis step. Here, it was demonstrated that hydrothermal pretreatment of PPR led to a higher release of reducing sugars as compared to that in acid and alkali pretreatment. A response surface methodology was used to optimize the enzyme hydrolysis of pretreated PPR for production of reducing sugars. It has been shown that substrate concentration, $\mathrm{pH}$, and temperature have significant effects on the enzymatic conversion of polysaccharides contained in the pretreated PPR. A trial was conducted to evaluate the convertibility of released reducing sugars into ethanol, which showed that $30 \mathrm{~g} / \mathrm{L}$ of ethanol could be obtained when $0.15 \mathrm{~g} / \mathrm{L}$ of ammonium sulfate was added to the fermentation medium. A comparative study between acid and enzyme hydrolysis of PPR was investigated. Results show that enzyme hydrolysis offers high yield of bioethanol production than acid hydrolysis. Based on these results, it could be considered that 0.1 million tons of ethanol could be retrieved per million tons of PPR per year. These results are highly promising and offer an interesting strategy for potato peel valorization.

\section{Acknowledgments}

The authors would like to acknowledge the researchers working in the laboratory of pulp and paper science and graphic arts, Grenoble Institute of Technology for providing facilities and technical support for MEB characterization of different samples.

\section{References}

1. Tian, X.-f.; Fang, Z.; Guo, F., Impact and prospective of fungal pre-treatment of lignocellulosic biomass for enzymatic hydrolysis. Biofuels, Bioproducts and Biorefining 2012, 6, (3), 335-350. 
$2 . \quad$ Pensupa, N.; Jin, M.; Kokolski, M.; Archer, D. B.; Du, C., A solid state fungal fermentationbased strategy for the hydrolysis of wheat straw. Bioresour Technol 2013, 149, 261-7.

3. Akpan, U. G.; Kovo, A. S.; Abdullahi, M.; Ijah, J., The production of ethanol from maize cobs and groundnut shells. AU J Technol 2005, 9, 106-110.

4. Data Source: F.O. Licht, c. i. R. F. A., Ethanol Industry Outlook 2008-2014 reports. Available at www.ethanolrfa.org/pages/annual-industry-outlook, Ethanol Industry Outlook 2008-2014 reports. In Renewable fuels association.

5. Lin, Y.; Tanaka, S., Ethanol fermentation from biomass resources: current state and prospects. Appl Microbiol Biotechnol 2006, 69, (6), 627-42.

6. del Campo, I.; Alegría, I.; Zazpe, M.; Echeverría, M.; Echeverría, I., Diluted acid hydrolysis pretreatment of agri-food wastes for bioethanol production. Industrial Crops and Products 2006, 24, (3), 214-221.

7. Arapoglou, D.; Varzakas, T.; Vlyssides, A.; Israilides, C., Ethanol production from potato peel waste (PPW). Waste Management 2010, 30, (10), 1898-1902.

8. dos Santos, T. C.; Gomes, D. P. P.; Bonomo, R. C. F.; Franco, M., Optimisation of solid state fermentation of potato peel for the production of cellulolytic enzymes. Food Chemistry 2012, 133, (4), 1299-1304.

9. Kosseva, M. R., Chapter 3 - Sources, Characterization, and Composition of Food Industry Wastes. In Food Industry Wastes, Webb, M. R. K., Ed. Academic Press: San Diego, 2013; pp 37-60.

10. Nelson, M. L., Utilization and application of wet potato processing coproducts for finishing cattle. Journal of animal science 2010, 88, (13 Suppl), E133-42.

11. Wu, D., Recycle Technology for Potato Peel Waste Processing: A Review. Procedia Environmental Sciences 2016, 31, 103-107.

12. Niphadkar, S. S.; Rathod, V. K., Ultrasound-assisted three-phase partitioning of polyphenol oxidase from potato peel (Solanum tuberosum). Biotechnol Prog 2015, 31, (5), 1340-7.

13. Mohdaly, A. A.; Sarhan, M. A.; Smetanska, I.; Mahmoud, A., Antioxidant properties of various solvent extracts of potato peel, sugar beet pulp and sesame cake. Journal of the science of food and agriculture 2010, 90, (2), 218-26.

14. Wishley, A; Rao, V. A., Potato Peel as a Source of Important Phytochemical Antioxidant Nutraceuticals and Their Role in Human Health - A Review. In Phytochemicals as Nutraceuticals Global Approaches to Their Role in Nutrition and Health, 2012.

15. Sonderegger, M.; Jeppsson, M.; Larsson, C.; Gorwa-Grauslund, M. F.; Boles, E.; Olsson, L.; Spencer-Martins, I.; Hahn-Hagerdal, B.; Sauer, U., Fermentation performance of engineered and evolved xylose-fermenting Saccharomyces cerevisiae strains. Biotechnology and bioengineering 2004, $87,(1), 90-8$.

16. Bansal, N.; Tewari, R.; Soni, R.; Soni, S. K., Production of cellulases from Aspergillus niger NS-2 in solid state fermentation on agricultural and kitchen waste residues. Waste management (New York, N.Y.) 2012, 32, (7), 1341-6. 
17. Ibbett, R.; Gaddipati, S.; Davies, S.; Hill, S.; Tucker, G., The mechanisms of hydrothermal deconstruction of lignocellulose: New insights from thermal-analytical and complementary studies. Bioresource Technology 2011, 102, (19), 9272-9278.

18. Khushal, B.; Praveen, V. V., Cellulolytic Enzymes Production via Solid-State Fermentation: Effect of Pretreatment Methods on Physicochemical Characteristics of Substrate. Enzyme Research 2011, 2011.

19. Didderen, I.; Destain, J.; Thonart, P., Le bioéthanol de seconde génération: la production d'éthanol à partir de biomasse lignocellulosique. Presses agronomiques de Gembloux: 2008.

20. Qi, B.; Chen, X.; Shen, F.; Su, Y.; Wan, Y., Optimization of Enzymatic Hydrolysis of Wheat Straw Pretreated by Alkaline Peroxide Using Response Surface Methodology. Industrial \& Engineering Chemistry Research 2009, 48, (15), 7346-7353.

21. Hahn-Hagerdal, B.; Galbe, M.; Gorwa-Grauslund, M. F.; Liden, G.; Zacchi, G., Bio-ethanol-the fuel of tomorrow from the residues of today. Trends in biotechnology 2006, 24, (12), 549-56.

22. John, R. P.; Nampoothiri, K. M.; Pandey, A., Fermentative production of lactic acid from biomass: an overview on process developments and future perspectives. Appl Microbiol Biotechnol 2007, 74, (3), 524-34.

23. Singh, A.; Tuteja, S.; Singh, N.; Bishnoi, N. R., Enhanced saccharification of rice straw and hull by microwave-alkali pretreatment and lignocellulolytic enzyme production. Bioresource Technology 2011, 102, (2), 1773-1782.

24. Dien, B. S.; Li, X. L.; Iten, L. B.; Jordan, D. B.; Nichols, N. N.; O’Bryan, P. J.; Cotta, M. A., Enzymatic saccharification of hot-water pretreated corn fiber for production of monosaccharides. Enzyme and Microbial Technology 2006, 39, (5), 1137-1144.

25. M, J. F. D. S. M., Bioethanol production from seaweed euchema cottoni by neutralization and detoxification of acidic catalyzed hydrolyzate. International journal of environnemental sciences and technology 2014, 5, 455.

26. Khawla, B. J.; Sameh, M.; Imen, G.; Donyes, F.; Dhouha, G.; Raoudha, E. G.; Oumèma, N.E., Potato peel as feedstock for bioethanol production: A comparison of acidic and enzymatic hydrolysis. Industrial Crops and Products 2014, 52, 144-149.

27. Richelle, A.; Ben Tahar, I.; Hassouna, M.; Bogaerts, P., Macroscopic modelling of bioethanol production from potato peel wastes in batch cultures supplemented with inorganic nitrogen. Bioprocess Biosyst Eng 2015, 38, (9), 1819-1833.

28. Fundora, N., Vldes, I., Garcia, R., Hernandez, L.M., Porto, O. and Gonzalez, M.D. , Influence of nitrogen salts on alcohol production. Revista ICIDCA Sobre Los Derivados De La. Cana. Dec Azucar, 2000, 34.

29. Ververis, C.; Georghiou, K.; Danielidis, D.; Hatzinikolaou, D. G.; Santas, P.; Santas, R.; Corleti, V., Cellulose, hemicelluloses, lignin and ash content of some organic materials and their suitability for use as paper pulp supplements. Bioresource Technology 2007, 98, (2), 296-301.

30. Miller, Use of dinitrosalicylic acid reagent for determination of reducing sugars. Anal chemstry 1959, 31, 428. 
31. Chinoy, J. J., A new iodine method for the determination of starch. Part V. Starch in leaf material. Analyst 1938, 63, (753), 876-883.

32. Uma, C.; Muthulakshmi, C.; Gomathi, D.; Gopalakrishnan, V. K., Fungal Invertase as Aid for Production of Ethanol from Sugarcane Bagasse. Research Journal of Microbiology 2010, 5, (10), 980.

33. Makawi., S. Z. A.; Taha., M. I.; Zakaria., B. A.; Siddig., B.; Mahmod., H.; Elhussein., A. R. M.; kariem., E. A. G., Identification and Quantification of 5-Hydroxymethyl Furfural HMF in

Some Sugar-Containing Food Products by HPLC. Pakistan Journal of Nutrition 2009, 8, 1391-1396.

34. Zeng, M.; Mosier, N. S.; Huang, C. P.; Sherman, D. M.; Ladisch, M. R., Microscopic examination of changes of plant cell structure in corn stover due to hot water pretreatment and enzymatic hydrolysis. Biotechnology and bioengineering 2007, 97, (2), 265-78.

35. Wajira S. RatnayakE, G., Chika Otani, David S. Jackson, DSC enthalpic transitions during starch gelatinization in excess water, dilute sodium chloride and succrose solutions. Faculty Publications in Food Science and Technology 2012, 5, (15).

36. Chaturvedi, V.; Verma, P., An overview of key pretreatment processes employed for bioconversion of lignocellulosic biomass into biofuels and value added products. 3 Biotech 2013, 3, (5), 415-431.

37. Stevulova, N.; Cigasova, J.; Estokova, A.; Terpakova, E.; Geffert, A.; Kacik, F.; Singovszka, E.; Holub, M., Properties Characterization of Chemically Modified Hemp Hurds. Materials 2014, 7, (12), 8131 .

38. Aiello, C.; Ferrer, A.; Ledesma, A., Effect of alkaline treatments at various temperatures on cellulase and biomass production using submerged sugarcane bagasse fermentation with Trichoderma reesei QM 9414. Bioresource Technology 1996, 57, (1), 13-18.

39. Jabasingh, A., Response Surface Methodology for the Evaluation and Comparison

of Cellulase Production by Aspergillus nidulansSU04 andAspergillus nidulans

MTCC344 Cultivated on Pretreated Sugarcane Bagasse. Chem. Biochem. Eng 2011, 25, 501.

40. Oh, S. Y.; Yoo, D. I.; Shin, Y.; Seo, G., FTIR analysis of cellulose treated with sodium hydroxide and carbon dioxide. Carbohydrate Research 2005, 340, (3), 417-428.

41. Rashid, I.; Omari, M. H. A.; Leharne, S. A.; Chowdhry, B. Z.; Badwan, A., Starch gelatinization using sodium silicate: FTIR, DSC, XRPD, and NMR studies. Starch - Stärke 2012, 64, (9), 713-728.

42. Wang, Z.; Keshwani, D.; Redding, A.; Cheng, J., Alkaline pretreatment of coastal bermudagrass for bioethanol production. ASABE Annual International Meeting; Rhode Island Convention Center Providence, Rhode Island 2008.

43. Sukumaran, R. K.; Singhania, R. R.; Mathew, G. M.; Pandey, A., Cellulase production using biomass feed stock and its application in lignocellulose saccharification for bio-ethanol production. Renewable Energy 2009, 34, (2), 421-424. 
44. Sindhu, R.; Kuttiraja, M.; Binod, P.; Janu, K. U.; Sukumaran, R. K.; Pandey, A., Dilute acid pretreatment and enzymatic saccharification of sugarcane tops for bioethanol production. Bioresource Technology 2011, 102, (23), 10915-10921.

45. Kim, H.; Kim, S.; Kim, C., The effects of nonionic surfactants on the pretreatment and enzymatic hydrolysis of recycled newspaper. Biotechnol. Bioprocess Eng. 2007, 12, (2), 147-151.

46. Peterson, Michelle E.; Daniel, Roy M.; Danson, Michael J.; Eisenthal, R., The dependence of enzyme activity on temperature: determination and validation of parameters. Biochemical Journal 2007, 402, (Pt 2), 331-337.

47. Soccol, C. R.; Vandenberghe, L. P. d. S.; Medeiros, A. B. P.; Karp, S. G.; Buckeridge, M.; Ramos, L. P.; Pitarelo, A. P.; Ferreira-Leitão, V.; Gottschalk, L. M. F.; Ferrara, M. A.; Silva Bon, E. P. d.; Moraes, L. M. P. d.; Araújo, J. d. A.; Torres, F. A. G., Bioethanol from lignocelluloses: Status and perspectives in Brazil. Bioresource Technology 2010, 101, (13), 4820-4825.

48. Sarkar, N.; Ghosh, S. K.; Bannerjee, S.; Aikat, K., Bioethanol production from agricultural wastes: An overview. Renewable Energy 2012, 37, (1), 19-27.

49. Modig, T.; Lidén, G.; Taherzadeh, M. J., Inhibition effects of furfural on alcohol dehydrogenase, aldehyde dehydrogenase and pyruvate dehydrogenase. Biochemical Journal 2002, 363, (Pt 3), 769-776.

50. Rachma Wikandari, R. M., Siti Syamsiyah, Ririn Muriana and Yuliana Ayuningsih, Effect of Furfural, Hydroxymethylfurfural and Acetic Acid on Indigeneous Microbial Isolate for Bioethanol Production. Agricultural journal 2010, 5, 105-109.

51. Bell, S.-J.; Henschke, P. A., Implications of nitrogen nutrition for grapes, fermentation and wine. Australian Journal of Grape and Wine Research 2005, 11, (3), 242-295.

52. Kim, T. H.; Taylor, F.; Hicks, K. B., Bioethanol production from barley hull using SAA (soaking in aqueous ammonia) pretreatment. Bioresource Technology 2008, 99, (13), 5694-5702.

53. Gouvea, B. M.; Torres, C.; Franca, A. S.; Oliveira, L. S.; Oliveira, E. S., Feasibility of ethanol production from coffee husks. Biotechnol Lett 2009, 31, (9), 1315-9. 